\title{
Factors Affecting Use Levels of Farmyard Manure in Vihiga County, Kenya
}

\author{
Mary J. Kipsat* D.O. Osewe Mose Phoebe Bwari \\ Department of Agricultural Economics and Rural Development, Maseno University, \\ P.O. Private Bag, Maseno, Kenya
}

\begin{abstract}
Several studies have been done to determine factors affecting adoption of new technologies. However, few or no studies have been carried out to determine factors believed to affect use level of recommended technology packages. Majority of farmers in the study area had used farmyard manure in crop production. Framers however used suboptimal levels resulting in low crop yields. This happens despite the fact that farmers are aware of the recommended levels needed for appreciable yields to be realized. Studies need to be done to determine why farmers use suboptimal levels of farmyard materials in the study area. The study analyzed the factors believed to affect intensity of use of farmyard fertilizers with the aim of identifying the role each factor plays in determining level of use of farmyard fertilizers among smallholder farmers. Stratified random sampling was used to select respondents. A total of 120 farmers were selected to provide data needed for the study. Data was collected from three out of six divisions of Vihiga County. At least 30 farmers were selected from each division. Primary data was collected using questionnaires and data collected was analyzed using regression analysis. The results of the analysis indicated that a number of factors were significant in determining use levels of farmyard manure. Out of the ten factors believed to affect use intensity of farmyard manure, five were statistically significant at $95 \%$ confidence level. The results of the regression analysis showed that education level of decision-maker, farm size, income of household, availability of labor and access to manure were significant at $95 \%$ level in explaining use intensity of farmyard manure in the study area. The study recommended that factors affecting use levels of farm yard manure be addressed with the aim improving the amounts used in order to bridge the gap between the current use level and the recommended level of farmyard fertilizers among smallholder farmers.
\end{abstract}

Keywords: Factors affecting, Use Levels, Farmyard Manure, Kenya

DOI: $10.7176 / \mathrm{JESD} / 12-24-05$

Publication date: December $31^{\text {st }} 2021$

\section{Introduction}

Several authors such as Mengistu and Siegfrie (2011), Yuan, Hong, Hans-Joachim and Abbaspour (2010), Waithaka, Thornton, Shepherd, Keith and Ndiwa (2007) and Feather and Gregory (1994) noted that technologically sound practices able to improve soil fertility and at least as profitable as practices in place are preferably chosen by farmers. The challenge is for researcher to conduct research and fill information gaps on technical efficiency and on determinants of use levels of promoted technologies. Farmyard manure, if used in the right amounts can be as effective as chemical fertilizers. Farmyard manure is often applied by broadcasting and hoeing or raking it into the top soil. Chemical fertilizers are required in small amounts (50 $\mathrm{kg}$ per ha) while farmyard materials are required in large amounts ( 5 tons/ha) to meet plant nutrient requirements. Chemical fertilizers contain soluble mineral salts that plant roots can absorb quickly explaining why they are needed in small amounts. such as farmyard in study area. Generally, two animals producing high quality manure would be needed to supply a $2 \mathrm{t}$ maize crop but 8 animals are needed if the quality is low (Yuan et al, 2010; Probert et al., 1993). Zero grazed animals produce an estimated 1 to 1.5 tonns / animal/year (Strobel, 1987). Selected factors were analyzed to determine how they affected use level of farmyard manure in the study area. The factors postulated to determine use level of farmyard manure were hypothesized not to significantly affect use levels of farmyard manure.

There are many sources of farmyard materials but farmyard manure was selected to analyze use level of farmyard materials in the study area. This is because majority of farmers in the study area used farmyard manure as the only source of fertilizer in subsistence food production in the study area. Removal of fertilizer subsidies by most African governments as part of Structural Adjustment Programmes (SAPs) in the 1980s tripled or quadrupled fertilizer prices in relation to crop prices in African countries (Joshua \& Jayne, 2010; Bumb \& Baanante, 1996). Consequently, chemical fertilizer recommendations for major soil types and individual crops in Kenya's representative soils ceased to be adhered to by most smallholder farmers in Kenya (Joshua and Jayne, 2010; Government of Kenya [GoK], 1996). Governments have tried to subsidize fertilizer and seed prices for small scale farmers with the aim of improving national food security resulting in improved yields among small scale farmers. Despite this the price of fertilizers in rural areas of Africa is at least twice international price due to cost of transport, import duties and high tax charges (Bumb and Baanante, 1996). Fertilizer prices in Africa have been rising despite real international prices falling (Ariga \& Jayne, 2010; Dorfman, 1996). 
Farmyard manure consists of cattle, sheep, goat or chicken waste. Low quality crop residues are fed to cattle and manure is used to fertilize crops. Farmyard is spread evenly in the field then worked out into the soil soonest possible to avoid nutrient losses. They can also be applied into furrows dug $20 \mathrm{~cm}$ deep and mixed with soil while covering furrows. It can also be applied in planting holes and incorporated into soil before planting. Farmyard is available in most households but in small quantities, availability depending on number of livestock kept in each household. Farm yard Manure is prepared basically using cow dung, cow urine, waste straw and other dairy wastes. Farmyard manure is very rich in plant nutrients. A small portion of Nitrogen is directly available to the plants while a larger portion is made available as and when the farmyard decomposes. The constraints to use of farmyard manure include unavailability, bulkiness and high labor requirements in dung handling at the farm, storage and application in the fields (Mengistu \& Siegfrie, 2011; Yuan, et al, 2010), Waithaka et al, 2007; Feather \& Gregory (1994). Farmyard manure is also associated with weeds as the manures often harbor indigestible weed seeds that sprout on cropped fields resulting in associated weed control costs. Farmyard fertilizers have residual effects in soil and use of recommended levels result in as good crop yields as chemical fertilizers (Kwesiga et al., 1998); Adiningsih et al., 1987). Despite known benefits of farmyard fertilizers few farmers use them at optimal levels. The purpose of this study was to analyze factors that determine the application rate of farmyard manure in farmers' fields.

\section{Methodology}

\subsection{The Study area}

The study was carried out in Vihiga County and covered three divisions namely; Emuhaya, Luanda and Sabatia. The selected divisions represented the two main AEZs of Vihiga County. Vihiga County was selected because it represented the western Kenya region and was also one of the most populous rural counties with smallholder farms ideal for use of farmyard fertilizers. The County's warm and humid climate supports growing of most crops. However, soils are of low fertility, limited water-holding capacity and are prone to erosion due to their sandy texture, high land use intensity and heavy rainstorms. Widespread N\&P deficiencies in soils due to continuous cropping, nutrient leaching (Niang' et al., 1996) and inability of smallholder farmers to invest on fertilizers to replace the lost nutrients (Okalebo et al., 1996) has led to low agricultural productivity in the County. There is thus need to determine how factors believed to affect use of farmyard materials determine intensity of use of farmyard manure and to develop policy recommendations to promote the adoption of recommended levels of farmyard used by most farmers in study area.

\subsection{Sampling Procedure and Sample Size}

The universe of the study was divided into three sampling units represented by Emuhaya, Luanda and Sabatia divisions of Vihiga County. The selection was based on agro-ecological zonation since most farmers in the County used farmyard manure for soil fertility in subsistence food production. Stratified random sampling was done through use of random numbers as recommended by Kerlinger, 2014; Mugenda \& Mugenda, 2003; Kothari \& Garg, 2014). When people living in a given area are randomly selected every one stands a chance of falling into the sample (Kothari \& Garg, 2014). A household in this study was the enumeration unit and was defined as a decision-making unit at farm level. At least two households were selected from each sub-location. Data was collected from 20 sub-locations in which a total of 80 respondents were interviewed giving a sample size of 80 .

\subsection{Sample Frame}

The target population was the set of resource poor farmers who used farmyard manure in subsistence maize and bean production in the study area. This study recognized the role maize and bean production played in meeting food needs of residents in Vihiga County.

\subsection{Data Collection}

Questionnaires were first pre-tested with a random sample of 8 resource poor farmers in Sabatia division. Corrections and adoption of the questionnaires to the field situation was made before actual data collection was carried out. Information concerning households was provided by members of households who were mainly wife, husband or both. Four enumerators trained on how to use the pre-tested questionnaires to collect data were used to collect the needed data.

\subsection{Types and Sources of Data Collected}

Primary was collected for this study. Primary data included those on incomes, use level of farmyard manure by sampled households, age of members of household needed for determining dependency ratios, availability of farmyard manure, education level of head of household, farm sizes, household size, frequency of extension visits to farmer's field, incomes levels of farmers.

To get information on the estimates of family income, the respondents were interviewed on returns from a 
range of farm enterprises, and incomes from non-farm sources such as salaried employment, business and remittances. Information on use levels of farmyard manure were obtained from selected farmers. The information collected from interviewed farmers was complemented with data available in KARI-Kakamega Library.

\subsection{Data Analysis}

A multiple regression model was carried out to analyze the relationship between 10 factors believed to determine use level of farmyard manure and the use intensity of the farm yard manure as recommended by Kerlinger, 2014; Kothari. \& Garg, 2014 and Koul, 2009.The regression had intensity, kg/ ha of farmyard (Y) as the dependent variable and 10 independent variables that were specified in the simple regression model below.

$\mathrm{Y}=\alpha_{0}+\alpha_{1} \mathrm{X}_{1}+\alpha_{12} \mathrm{X}_{2}+\alpha_{3} \mathrm{X}_{3}+\alpha_{4} \mathrm{X}_{4}+\alpha_{5} \mathrm{X}_{5}+\alpha_{6} \mathrm{X}_{6}+\alpha_{7} \mathrm{X}_{7}+\alpha_{8} \mathrm{X}_{8}+\alpha_{9} \mathrm{X}_{9}+\alpha_{10} \mathrm{X}_{10}$-----equation 2.1

Where;

$\mathrm{Y}=\mathrm{kg} / \mathrm{ha}$ of farmyard applied by farmer to crop per planting season

$\mathrm{X}_{1}=$ Age category of household decision maker; $\mathrm{X}_{2}=$ Household dependency ratio; $\mathrm{X}_{3}=$ Education level of decision maker; $X_{4}=$ Farm Size in ha; $X_{5}=$ Income level of household head in Kshs; $X_{6}=$ Household labor availability; $X_{7}=$ Sex of head of household; $\mathrm{X}_{8}=$ Frequency of extension visits; $\mathrm{X}_{9}=$ Family size; $\mathrm{X}_{10}=$ Availability of farmyard manure.

\section{Results and Discussions}

Table 1 contains summary results of the regression analysis of the 10 factors believed to affect use levels of farmyard in Vihiga County, Kenya.

Table 1: Factors Affecting Use Level of Farmyard Manure in Vihiga County, Kenya

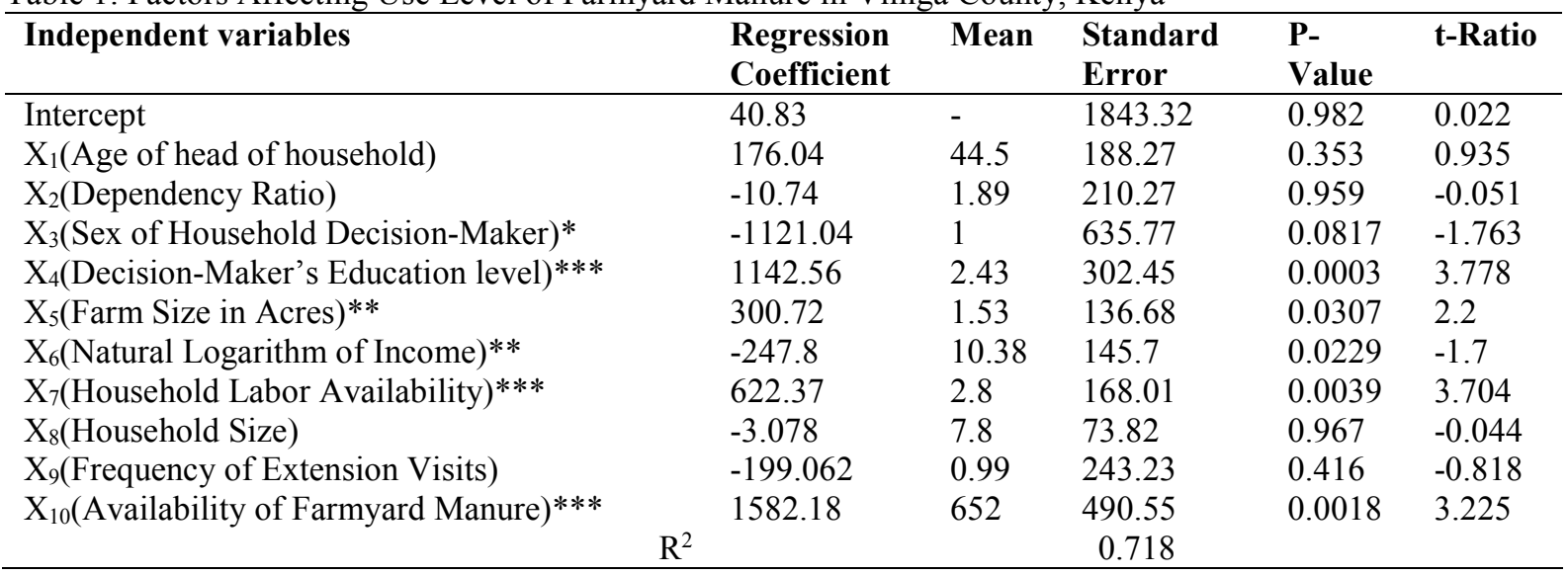

Source: Data Analysis in this Study (2001)

* Significant at 10\% level, ** significant at 5\% level, *** significant at $1 \%$ level

The regression model estimate was given as: $Y=40.83+176.04 \mathrm{X}_{1}-10.74 \mathrm{X}_{2}+1142.55 \mathrm{X}_{3}+300.7 \mathrm{X}_{4}-$ 247.8 $\mathrm{LnX}_{5}+622.37 \mathrm{X}_{6}-1121.04 \mathrm{X}_{7}+199 \mathrm{X}_{8}-3.08 \mathrm{X}_{9}+1582.18 \mathrm{X}_{10}$

\section{Discussions}

Five variables: dependency ratio, female gender of head of household, family size, that negatively affected use level of farmyard manure and; labor availability and frequency of extension visits that positively affected level of use of farmyard manure were not statistically significant at 95\% level. The results also showed that the independent variables explained $71.8 \%$ of variation in use levels of farmyard manure. The discussion focuses on five variables (age of decision maker, education level, farm size, household income and availability of farmyard manure) whose effects on use level of farmyard manure were significant at $95 \%$ level.

The effect of age of head of household on intensity of use of farmyard manure was positive and significant at 95\% confidence level. This could be explained by the fact that older farmers are likely to be more endowed with resources needed to acquire manure. Older farmers were also likely to own animal herds and more likely to prefer use of farmyard manure.

The effect of level of formal education of decision-maker on use level of farmyard manure was positive and significant at $95 \%$ confidence level. Formal education tended to raise awareness on recommended levels of manure. Education has been found to promote adoption of recommended practices and reduce lag time between knowledge and technology use. The average number of years of formal education from this study was five years. Most decision-makers had at least secondary school level of education while another $25.6 \%$ had college level of education. This is an indication of a high literacy level of famers sampled in the study area. High literacy level meant that famers were able to understand the need for use of promoted new technologies with ease. From the analysis, $11.1 \%$ of household heads were illiterate while the rest $(88.9 \%)$ had formal education. The study area 
also had several adult education literacy centers with programs that targeted adults who did not manage to acquire formal education during their formative years.

The regression analysis indicated that farm size positively contributed to use level of farmyard in study area. The effect was statistically significant at $95 \%$ level. Larger farm sizes were associated with many people living on the farm thus likely have more social capital that tend to provide labor for applying farmyard manure that is highly labor intensive. Farmers with larger land sizes also tended to have pastures and thus kept animals on their farms, increasing the availability of manure, improving use levels of farmyard manure. The study established that most (41.1\%) households owned between 0.4 and 0.76 ha of land, the average land size being 0.6 ha/household, equivalent to 0.075 ha per capita. Small-scale farming was the major pre-occupation of majority of families, supporting 53,528 households. The major crops grown in the study area included maize, beans, cassava and bananas. Maize was the preferred staple food and the main crop contributing about $80 \%$ of calorie intake.

The simple regression analysis showed a negative and statistically significant relationship between use intensity of farmyard and income at $95 \%$ level. The finding was contrary to expectation as income often results in positive effect on technology use. The observation could be explained by the fact that incomes are generally low and little of it was directed to purchase of agricultural inputs. Higher income group farmers tended to regard farmyard as 'inferior good.' An inferior good is defined as an item whose use decline as income of users rise. As incomes improved, farmers allocated more of it to chemical fertilizers and hybrid maize seed and less to acquiring farmyard manure. Most (71\%) of farmers in the study area got incomes less than the national mean of Kshs $2,307 /$ month $(\mathrm{GoK}, 1994)$. Most of the income in the County was used to purchase food and meet education needs of children. Shepherd and Soule (1998) in a survey of households in the County classified 55\% of the farmers as low resource endowment farmers and $35 \%$ as medium resource endowment farmers. Majority $(37.8 \%)$ of the sampled farmers reported earning incomes of less than KShs. 9999/ year while 35.6\% of them reported earning household incomes of between KShs. 10,000 and 49,999/year, with an average household income of KShs. 12,000/ year. The rest $(26.6 \%)$ of families reported getting incomes of more than Kshs. 50,000/year, with an average income of KSh. 65000/year. Off farm income from salaried employment, casual wages, and remittances contributed the largest proportion (66\%) of income while agriculture contributed to the smallest proportion among sampled households.

Effect of family labor availability on use level of farmyard manure was positive and significant at $95 \%$ level. Labor is important in accessing, preparing and applying farmyard. Most farmers in the study area were resource poor and could not afford to spend limited incomes on hire of farm labor that costed about KShs. 150/man day at expense of basic needs like food, clothing and education of children. Family labor determined use intensity of farmyard manure in study area. Though labor was available, people did not have incentives to release labor into farming that had low returns. Despite the high population densities in Vihiga County, few farmers hired labor while few people were willing to serve as farm laborers limiting most households to using family labor. In addition, the high population density characteristic of the study area did not translate into labor as most households had too young $(<15$ years old $)$ to be engaged in gainful farm employment members.

Availability of farmyard manure was positively related to use level of the manure. The relationship was statistically significant at $95 \%$ level. Availability of farmyard manure was important in increasing use level of the manure. Farmyard manure contains low plant nutrient concentrations thus the need to use it in large amounts calling for the manure to be available. Most farmers in the study area owned a few local cattle which were on average 4 in number, kept mostly as liquid assets and for milk, manure and beef production. Only $5-7 \%$ of the farmers possessed an improved cow breed, though the number was increasing due to the rising demand for milk and promotion of livestock development by the GoK and NGOs that operated in the region. Local cows were grazed in and around homesteads and were fed through cut and carry Napier grass and crop residues. Improved cattle were mainly kept in zero grazing units and feed supplements to Napier grass were required. A third of the farmers bought fodder, mainly in the dry season and during periods of shortages. Goats, sheep and chicken were also kept in numbers varying from household to household contributing to household farmyard manure. Livestock production is notably small in Vihiga County. This was due to a number of reasons that included livestock diseases, limited veterinary services, cattle theft and shortage of browse caused by land scarcity. Yuan Zhou, et al, 2010; Waithaka et al, 2007 and. Makokha (1999) noted that ability of farmers to collect and use adequate amounts of manure is affected by a number of factors that included availability of labor to gather and transport manure to seedbeds, farmers' appreciation of contribution of manure to improved crop production, knowledge of collection and storage of manure, size of land and number of livestock and, the layout of animal sheds.

\section{Conclusions}

Ten variables were analyzed to determine their effect on use levels of farmyard. The results showed that variables included in the model accounted for $71.8 \%$ of the variation in use level of farmyard in farmers' fields. Regression analysis showed that education level of decision-maker, farm size, income of household, availability of labor, access to manure were significant in explaining use levels of farmyard manure at $95 \%$ level. The hypothesis that 
factors postulated to affect use level of farmyard manure had no significant effect on farmyard manure intensity of use was rejected. This is because five out of ten factors believed to affect use intensity were significant at $95 \%$ level.

Research efforts should be towards strategies that will ensure that farmers use recommended levels of farmyard materials. Factors that negatively affect use of farmyard and those that promote use farmyard should be considered in fertilizer use policy recommendations.

\section{References}

Adiningsih, J., Prihatini, T., Purwal, J., and Kentjanasam A. (1987). Development on Integrated Fertilizer Management to Sustain Food Production in Indonesia: The Use of Organic and Biofertilizer In: Indonesian Agricultural Research and Development Journal. Vol.19. No.4

Bumb, B. L. and Baanante, C. A. (1996). The Role of Fertilizer in Sustaining Food Security and Protecting the Environment to 2020. Food, Agricultural and the Environment. Dis. Paper 17 International, Washington D.C.

Feather, P.M. and Gregory, S.A. (1994. Role of Information on Adoption of Best Management Practices for Water Quality Management. Willey Online Library. Agricultural Economics/ Volume II, Isuuue 2-3

GoK (1996): Republic of Kenya (1996): Economic Management for Renewed Growth Sessional Paper No. 11. Government Printers, Nairobi Kenya.

ICRAF (1996). International Centre for Research in Agroforestry, Kenya (1996) Annual Report.

Joshua Ariga and T. S. Jayne (2010). Fertilizer in Kenya: Factors Driving the Increase in Usage by Smallholder Farmers.

Kerlinger, F.N. (2014). Foundation of behavioral research. Surjeet Publication, Rinehart and Winson, Inc. New York: 379.

Kothari, C.R. \& Gaurav Garg. (2014). Research methodology. Methods and techniques. Third edition. New Age International Publishers.

Koul, L. (2009). Methodology of educational research. 4th Edition Vikas Publishing House PVT Ltd. New Delhi.

Kwesiga R.S., Franzels., Place, F., Phiri, D. and Simwanza, C.P (1998). Sesbania sesban Improved Fallows in Eastern Zambia. Their Interception, Development and Farmer Enthusiasm. In Buresh, E .J. and Cooper, P.J. (ed.).The Science and Practice of Short term Improved Fallows. Kluwer Academic Publication Dordrecht, the Netherlands.

Makokha, M. O., (1999). An Economic Analysis of Farmer's Perception and Adoption of Alternative Soil Nutrient Replenishment Technologies in Western Kenya. Master of Philosophy Thesis, Moi University. Kenya.

Mengistu K, and Siegfried B (2011). Determinants of Manure and Fertilizer Applications in Eastern Highlands of Ethiopia. Quarterly Journal of International Agriculture 50 (2011), No. 3: 237-252

MoA (1999). Ministry of Agriculture Vihiga District (1999) Annual Report

Mugenda, O.M. \& Mugenda, A.G. (2003). Research methods, qualitative and quantitative approaches. ACTS Press-African Centre for Technology Studies. Nairobi, Kenya.

Niang', A. I., Amadolo, B. A., Gathumbi, S. M., Otieno, J. H., Obonyo, C. O. and Obonyo, E. (1996). KEFRI/KARI/ICRAF - AFRENA, Maseno Project Report No. 10.

Okalebo J. R. Woomer, p. L, Maritim, H. K. Kapkiyai J. and Mwakuko P. E. (1996). Phosphorous Research Exploratory Project for Western Kenya (PREP). Project Proposal Presented to "Rockefeller foundation, Forum on Agricultural Resources Husbandry.

Probert M.E., Keating B.A., Thompson J.P. (1995). Modeling Water, Nitrogen and Crop Yield for Long Term fallow management experiment. Australian Journal of Agric Economics

Shepherd, K. D. and Soule M. J. (1998). Assessment of the Economic and Ecological Impacts of Agroforestry and other Soil Management Options on Western Kenya Farms Using A Dynamic Simulation Model. Agricultural Ecosystem Environment. (In Press).

Strobel, H. (ed) (1987). Fertilizer Use Recommendation Project Report: Annex III. Description of the first Priority Sites in the Various Districts Ministry of Agriculture, National Research Laboratories, Nairobi Kenya. .

Vihiga County Development Plan (1994-1996), Vihiga County Development plan 2017-2021.

Waithaka, M., Thornton, P., Shepherd, K and Ndiwa, N. (2007). Factors affecting the use of fertilizers and manure by smallholders: the case of Vihiga, western Kenya. Nutrient Cycling in Agroecosystems.

Yuan Zhou, Hong Yang, Hans-Joachim Mosler and Karim C. Abbaspour (2010). Factors affecting farmers' decisions on fertilizer use: A case study for the Chaobai watershed in Northern China. The Journal of Sustainable Development Vol. 4, Iss. 1 (2010), Pp. 80-102

\section{First Author Mary J. Kipsat}

Prof. Mary Kipsat is currently the Deputy Vice Chancellor Academic and Student Affairs, Maseno University. She is an Associate Professor of Agricultural Economics and Resource Management and an alumnus of University 
of Nairobi and Moi University in Kenya. She graduated at the University of Nairobi with a Bachelor of Science in Agriculture degree in 1996. Mary obtained Masters in Agricultural Economics and Resource Management in 2002 and Doctorate in Agricultural Economics and Resource Management in 2006, both at Moi University. She was first employed in 1997 as Agricultural Officer in the Ministry of Agriculture, Kenya. She Joined Moi University as Tutorial Fellow in 2004 and has risen through the ranks to current position as Associate Prof. She has teaching and student supervision experience at University level spanning from 2004. She served as Head of Department of Agricultural Resource Economics and Management and Dean, School of Business and Economics before being appointed Deputy Vice-Chancellor, Academic and Student Affairs at Maseno University in 2014. She is actively involved in research, outreach and community service. She has attended a number of conferences, workshops and seminars in which she has presented research papers and had her management, administrative, research and teaching skills sharpened. She has undertaken a number of researches that include MBILI (Managing Beneficial Interactions in Legume Intercrops) project that was funded by Rockefeller Foundation and carried out in western Kenya (Uasin Gishu, Siaya and Bungoma). She has also undertaken research on non-conventional fertilizer technologies in Vihiga County and on socioeconomics of soil conservation in Kericho County. Prod. Kipsat currently has a total of thirty-five (35) publications in refereed journals, eight (8) book chapters and seventy-four (74) articles published as conference proceedings. She has supervised a total of eight (8) doctorate candidates who have all graduated, Fifty-eight (58) masters who have all graduated and several undergraduate students.

\section{Second Author. Daniel.O. Osewe}

Dr. Osewe, D.O is a lecturer in the Department of Agricultural Economics and Rural Development (AERD), School of Agriculture, Food Security and Environmental Sciences (SAFSES), Maseno University. He holds a PhD in Agricultural Extension with a minor in Agricultural Economics and Animal Science from Mahatma Phule Agricultural University, India, MSc in Agricultural Extension from Egerton University and BSc in Agriculture (Agricultural Economics Option) from University of Nairobi both in Kenya. He helped develop PhD with course work and MSc curricula for both Maseno University and Jaramogi Onginga Odinga University of Science and Technology (JOOUST). He reviewed Bachelor of Science Agricultural Education and Extension (BSc AGED) with Information Technology (IT) for Maseno University with was accepted by Commission for University Education (CUE) in 2020. Dr. Osewe currently has a total of eight (8) publications in refereed journals, one (1) book chapters and three (3) international conference presentations. He is currently supervising (1) doctoral scholar and eight (8) masters students. He is a Life member, International Society of Extension Education (INSEE), Nagpur, India; Maharashtra Society of Extension Education (MSEE), Pune, India in 2013; Member, Kenya Society of Agricultural Professionals (KESAP) in 2009, Nairobi, Kenya; Animal Production Society of Kenya (APSK) in 1997, Nairobi and World Veterinary and Poultry Association (WVPA)-Kenya chapter in 2018.

\section{Third Author, Mose Phoebe Bware}

Dr. Phoebe Bwari Mose is a Lecturer in the Department of Agricultural Economics and Rural Development, Maseno University. She is a Doctor of Philosophy (PhD.) graduate in Agricultural Economics from Maseno University, Kenya. She is also a holder of a MSc. degree in Agricultural Economics with specialization in Production Economics, Marketing and Rural Development and a BSc. degree in Agricultural Economics and Rural Development both from Moi University. Apart from teaching, her research interests include: Agribusiness, Food Security, Risk Management, Marketing, Production Economics Rural Development and Value Chain Analysis. 